\title{
Formation of disulfonated poly(arylene ether sulfone) thin film desalination membranes by solvent-free melt extrusion
}

\author{
Hee Jeung $\mathrm{Oh}^{\mathrm{a}}$, Jaesung Park ${ }^{\mathrm{a}}$, Sebnem Inceoglu ${ }^{\mathrm{b}}$, Irune Villaluenga ${ }^{\mathrm{c}, \mathrm{d}, \mathrm{f}}$, Jacob Thelen ${ }^{\mathrm{f}}$,
} Xi Jiang ${ }^{\mathrm{e}}$, James E. McGrath ${ }^{\mathrm{g},+}$, Donald R. Paul ${ }^{\mathrm{a}, *}$

\begin{abstract}
${ }^{a}$ Department of Chemical Engineering, The University of Texas at Austin, Austin, TX 78712, USA
${ }^{b}$ Lawrence Berkeley National Laboratory, Berkeley, CA 94720, USA

${ }^{c}$ Environmental Energy Technologies Division, Lawrence Berkeley National Laboratory, Berkeley, CA 94720, USA

'Joint Center for Energy Storage Research, Lawrence Berkeley National Laboratory, Berkeley, CA 94720, USA

${ }^{e}$ Materials Sciences Division, Lawrence Berkeley National Laboratory, Berkeley, CA 94720

${ }^{f}$ Department of Chemical and Biomolecular Engineering, University of California, Berkeley, Berkeley, CA 94720, USA

${ }^{g}$ Department of Chemistry, Virginia Polytechnic Institute and State University, Blacksburg, VA 24061, USA

${ }^{+}$Deceased
\end{abstract}

\author{
${ }^{*}$ Corresponding author: Donald R. Paul ${ }^{\mathrm{a}, 1}$ \\ Address: ${ }^{1}$ The University of Texas at Austin, McKetta Department of Chemical Engineering, \\ 1 University Station, Mail Code: C0400, Austin, TX 78712, USA \\ Email: drp@che.utexas.edu, phone: 512-471-5392
}

Manuscript in preparation for submission to

\section{Polymer}

December 2, 2016 


\begin{abstract}
In this study, we discuss a new membrane formation route for preparing sulfonated polysulfone desalination membranes by solvent-free melt processing. Singlelayer membranes composed of a $20 \mathrm{~mol} \%$ disulfonated poly(arylene ether sulfone) random copolymer (BPS-20K) and poly(ethylene glycol) (PEG) plasticizers were successfully prepared by using melt extrusion. The chemical integrity of the components in the BPS-20K/PEG membranes was maintained after the extrusion process, as confirmed by ${ }^{1} \mathrm{H}$ NMR and FT-IR analysis. Although some of the films appeared opaque after extrusion, this was found to be due to surface roughness. Other factors that might lead to film opacity, such as phase separation, crystallization, or micro-voids, were not found.
\end{abstract}

\title{
KEY WORDS
}

Sulfonated Polysulfone, Poly(ethylene glycol), Membrane, Melt Processing, Plasticizer 


\section{INTRODUCTION}

Most ionomer membranes used for water purification [1-3] and power generation $[4,5]$, are prepared by solution processing using large volumes of toxic solvents $[1,6]$. For example, currently widely used reverse osmosis desalination membranes, i.e., polyamide (PA) thin film composite membranes, are obtained at a solvent/water interface via interfacial polymerization $[1,2]$. Such conventional polymer membrane formation methods are environmentally unfriendly, and the cost associated with waste disposal is high. There is a clear need to prepare ionomer membranes in a more environmentally and cost effective manner.

Sulfonated aromatic hydrocarbons have been studied extensively as membrane materials for such future energy applications as fuel cells, reverse electrodialysis, and redox flow batteries. They are competitive with existing commercial perfluorosulfonated polymer membranes (e.g., Nafion ${ }^{\circledR}$ ) due to their low cost, simple chemistry, and excellent physical properties. In particular, sulfonated polysulfones have been investigated as candidate materials for reverse osmosis desalination [7-11] and fuel cell applications [5, 12-16] because of their excellent thermal and mechanical stabilities, as well as good selective ion transport properties [5, 7-16]. Furthermore, sulfonated polysulfone membranes may be prepared by solvent-free melt processing with an adequate plasticizer [17-24]. In principle, the glass transition temperature $\left(T_{\mathrm{g}}\right)$ and viscosity of sulfonated polysulfone are high because of the presence of sulfonate groups in the polymer matrix $[10,25]$, and, thus, the melt processing of sulfonated polysulfones is difficult $[26,27]$. However, a suitable plasticizer, for instance poly(ethylene glycol), has been explored to lower the $T_{\mathrm{g}}$ and viscosity of sulfonated polysulfones and thus enable the melt processing 
of such materials $[17,18,23,24,28]$. After melt processing, the plasticizer can be removed by water extraction before use [28]. In this research, we study this new membrane formation path to prepare sulfonated polysulfone desalination membranes by solvent-free melt processing.

Earlier, Bebin et al. explored the possibility of extruding proton exchange membranes for fuel cell applications (PEMFC) using post-sulfonated polysulfone [23, 24]. Several properties, such as proton conductivity and life span of extruded membranes, were reported; the extruded membranes showed decreased proton conductivity but increased life span compared to those of solution processed membranes. In addition, Sanchez et al. also prepared post-sulfonated polysulfone membranes for PEMFC applications by extrusion [19-21, 29, 30], investigated several candidate plasticizers for sulfonated polysulfones, and evaluated their rheological properties. However, previous work mainly focused on fuel cell applications, and to date no investigation has addressed the potential formation of desalination membranes by melt extrusion.

Additionally, the currently widely used membranes-i.e., polyamide (PA) membrane-for desalination have a thin film composite structure $[1,6]$, and similar composite structures may be obtained by employing a coextrusion process with proper support layer materials [31-33]. The thin film composite structure consists of a very thin, selective layer (in this work, sulfonated polysulfone), and a porous support layer. The thin selective layer offers high selectivity of salt, and the porous support layer provides mechanical stability while preserving high water flux. Polypropylene (PP) could be used as a candidate support material to form a composite structure, since desirable porosity in PP can be achieved by various methods, including post-coextrusion stretching $[31,34$, $35]$. 
In this work, disulfonated poly(arylene ether sulfone)s (BPS) random copolymers have been explored for desalination membrane materials, and poly(ethylene glycol), PEG, oligomers were selected as plasticizers to enable melt extrusion of the BPS polymers. In previous studies, we reported the effect of PEG oligomers on the $T_{\mathrm{g}}$ and viscosity of BPS/PEG blends and found the potential compositions of BPS/PEG blends that were rheologically matched with PP to form a composite structure $[17,18]$. Using this information, single layer films of BPS-20K/PEG blends were prepared.

Thin films of $20 \mathrm{~mol} \%$ disulfonated poly(arylene ether sulfone) random copolymer (BPS-20K)/PEG blends with uniform thickness $(20-40 \mu \mathrm{m})$ were produced by melt extrusion. It was of interest to determine whether chemical structure and morphologies of extruded films are comparable to those of solution cast films. The molecular structure and composition (i.e., PEG $\bar{M}_{n}$, and concentration) in the extruded films were examined using Proton Nuclear Magnetic Resonance ( ${ }^{1} \mathrm{H}$ NMR) and Fourier Transform Infrared Spectroscopy (FT-IR) analysis to detect any thermal degradation during melt extrusion. Some extruded films were rather opaque compared to transparent solution cast films, and the origin of this opaqueness was investigated. The factors leading to film inhomogeneity such as micro-voids, phase separation, or excessive crystallization were examined with Scanning Electron Microscopy (SEM), gas permeability measurements, and Differential Scanning Calorimetry (DSC). While the focus of this study is membrane formation, subsequent papers will report the PEG extraction kinetics from the extruded BPS-20K/PEG films, as well as the water and salt transport properties of the resulting pure BPS-20K membranes. 


\section{MATERIALS AND EXPERIMENTAL}

\subsection{Materials}

\section{Polymer: 20 mol\% disulfonated poly(arylene ether sulfone) (BPS-20K)}

Figure 1 shows the chemical structure of the disulfonated poly(arylene ether sulfone) random copolymer (BPS) used in this study. BPS polymers were synthesized directly from sulfonated monomers as established by McGrath and others $[9,10,17,36-$ 38]. Nomenclature for this polymer is BPS-XY, where $\mathrm{X}$ is the molar percentage (mol\%) of disulfonated monomer and $\mathrm{Y}$ indicates the cation forms in sulfonated groups, either $\mathrm{H}$ (acid form) or K (potassium form). For example, BPS-20K is in K (potassium) sulfonated form containing $20 \mathrm{~mol} \%$ of sulfonated polysulfone segments and $80 \mathrm{~mol} \%$ of nonsulfonated polysulfone segments.

The $20 \mathrm{~mol} \%$ disulfonated poly(arylene ether sulfone) random copolymer, BPS$20 \mathrm{~K}$, has an ion exchange capacity (IEC) of $0.92 \mathrm{meq} / \mathrm{g}$ and was selected for its thermal and mechanical stability, as well as its selective ion transport properties $[7,10,11,17]$. BPS-20K polymer synthesized by Akron Polymer Systems (Akron, OH) was used as received. Table 1 provides the characteristics of the BPS-20K polymer.

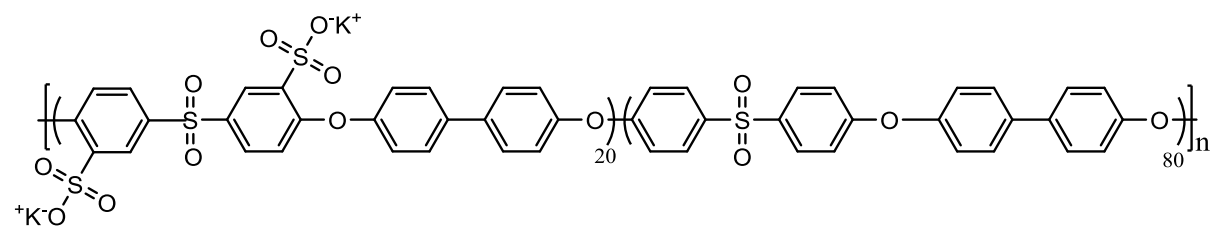

Figure 1 Chemical structure of $20 \mathrm{~mol} \%$ disulfonated poly(arylene ether sulfone) random copolymer (BPS-20K). 
Table 1 Properties of the BPS-20K polymer used in this study

\begin{tabular}{cccc}
\hline Material & $\begin{array}{c}\bar{M}_{w}{ }^{[\mathrm{a}]} \\
{[\mathrm{g} / \mathrm{mol}]}\end{array}$ & $\begin{array}{c}\mathrm{IV}^{[\mathrm{a}]} \\
{[\mathrm{mL} / \mathrm{g}]}\end{array}$ & $\begin{array}{c}T_{\mathrm{g}}{ }^{[\mathrm{b}]} \\
{\left[{ }^{\circ} \mathrm{C}\right]}\end{array}$ \\
\hline BPS-20K & 29,700 & 41.7 & 256 \\
\hline
\end{tabular}

[a] Determined by SEC using NMP with $0.05 \mathrm{M} \mathrm{LiBr}$ at $50{ }^{\circ} \mathrm{C}$. Note that specific refractive index increment $(\mathrm{dn} / \mathrm{dc})$ values were measured using an assumption of $100 \%$ mass recovery. $\mathrm{dn} / \mathrm{dc}$ values for BPS-20K polymers in this study are $0.17[\mathrm{~mL} / \mathrm{g}]$.

[b] Measured by DSC at $20^{\circ} \mathrm{C} / \mathrm{min}$

\section{Plasticizer: Poly(ethylene glycol) $200 \sim 400 \mathrm{~g} / \mathrm{mol}$}

Poly(ethylene glycol), PEG, oligomers with molecular weight $\left(\bar{M}_{n}\right)$ ranging between $200 \mathrm{~g} / \mathrm{mol}$ and $400 \mathrm{~g} / \mathrm{mol}$ were used as plasticizers for BPS-20K polymer [17, 18]. Glass transition temperatures $\left(T_{\mathrm{g}}\right)$ and melting points $\left(T_{\mathrm{m}}\right)$ of PEG oligomers are summarized in Table 2. PEG concentration ( $\mathrm{wt} \%)$ in the melt extruded membranes ranged between $20 \mathrm{wt} \%$ and $30 \mathrm{wt} \%$. The PEG oligomers were purchased from Sigma Aldrich (St. Louis, MO) and were used as received. Product information is as follows: PEG 200 Cat\# P3015, PEG 300 Cat\# 202371, and PEG 400 Cat\# 202398.

Table 2 Glass transition temperatures $\left(T_{\mathrm{g}}\right)$ and melting points $\left(T_{\mathrm{m}}\right)$ of PEG oligomers

\begin{tabular}{cccc}
\hline Material & $\begin{array}{c}\text { Average } \\
\bar{M}_{n}[\mathrm{~g} / \mathrm{mol}]\end{array}$ & $\begin{array}{c}T_{\mathrm{g}}{ }^{\mathrm{a}]} \\
{\left[{ }^{\circ} \mathrm{C}\right]}\end{array}$ & $\begin{array}{c}T_{\mathrm{m}}{ }^{\mathrm{a}]} \\
{\left[{ }^{\circ} \mathrm{C}\right]}\end{array}$ \\
\hline PEG 200 & 200 & -83 & - \\
PEG 300 & 300 & -76 & -15 \\
PEG 400 & 400 & -72 & 2 \\
\hline
\end{tabular}

[a] Measured by DSC at $20^{\circ} \mathrm{C} / \mathrm{min}$, Table 2 from Reference [17] 


\subsection{Experimental}

\subsubsection{Sample preparation}

\section{Melt extrusion}

Single layer, extruded films of BPS/PEG blends were prepared by a $5 \mathrm{ml}$ twin screw micro-compounder with an attached heated film die (width $=65 \mathrm{~mm}$ ) and film take-up system (DSM Xplore, The Netherlands). The desired amount of BPS-20K and PEG were weighed and carefully mixed before feeding to the micro-compounder. The micro-compounder was operated under an extra dry nitrogen atmosphere (99.9 \%, Matheson Tri-Gas, Austin, TX) to prevent polymer degradation. The processing temperature was selected to be $50 \sim 100{ }^{\circ} \mathrm{C}$ higher than the blend $T_{\mathrm{g}}$ and lower than the degradation temperature, $T_{\mathrm{d}}$, as reported previously $[17,18,28]$. The processing temperature was in the range of $220 \sim 250{ }^{\circ} \mathrm{C}$, depending on the blend compositions. More details can be found in previous reports $[17,18,28]$.

\section{Solution casting method}

A solution casting method was used to prepare thin $(30-40 \mu \mathrm{m})$, freestanding BPS-20K films. BPS-20K polymer was dissolved in N,N-dimethylacetamide (DMAc, Sigma Aldrich, Cat\# 39940) for 24 hours to prepare a $10 \mathrm{wt} \%$ polymer solution. This solution was cast onto a glass plate, and the solvent (DMAc) was evaporated by keeping it in an oven at $60{ }^{\circ} \mathrm{C}$ for 24 hours and then in a vacuum oven at $120{ }^{\circ} \mathrm{C}$ for an additional 48 hours. Residual solvent was further removed by soaking it for 24 hours in deionized (DI) water. $[9,17]$. Afterwards, peeled membranes were dried in a vacuum oven at 110 ${ }^{\circ} \mathrm{C}$ for 24 hours. 


\subsubsection{Film characterization}

\section{Differential scanning calorimetry (DSC)}

The glass transition, $T_{\mathrm{g}}$, temperatures of BPS-20K/PEG films were measured by using DSC (Q100, TA Instruments, New Castle, DE). A 5 mg polymer sample was weighed and then sealed in an aluminum pan for measurement. A DSC thermogram was recorded using a heating rate of $20{ }^{\circ} \mathrm{C} / \mathrm{min}$ in temperature ranges between $-90{ }^{\circ} \mathrm{C}$ and 350 ${ }^{\circ} \mathrm{C}$ under ultra-high purity nitrogen (UHP $99.999 \%$, Air Gas, Austin, TX). The $T_{\mathrm{g}}$ was reported as the mid-temperature of the heat capacity step change.

Fourier Transform Infrared Spectroscopy (FT-IR)

Attenuated Total Reflection (ATR) FT-IR (Nicolet 6700 FT-IR Spectrometer, Thermo Scientific, Waltham, MA) was employed to examine chemical structural changes in the BPS-20K and BPS-20K/PEG films. For each sample, 64 spectra at a resolution of 4 $\mathrm{cm}^{-1}$ were collected in air.

\section{Proton Nuclear Magnetic Resonance ( ${ }^{1}$ H NMR)}

A Varian DirectDrive spectrometer (Agilent Technologies, Santa Clara, CA) operating at $400 \mathrm{MHz}$ was used to record ${ }^{1} \mathrm{H}$ NMR spectra. ${ }^{1} \mathrm{H}$ NMR spectra were used to characterize chemical structure, degree of BPS-20K sulfonation, average molecular weights $\left(\bar{M}_{n}\right)$, and concentration (wt\%) of the PEGs in the BPS-20K/PEG films. NMR samples were prepared by dissolving $20 \mathrm{mg}$ of the films in $2 \mathrm{~cm}^{3}$ of $\left(\mathrm{CD}_{3}\right)_{2} \mathrm{SO}$, dimethyl sulfoxide-D6 (99.9 \%, Cat\# DLM-10, Cambridge Isotope Laboratories, Andover, MA). ${ }^{1} \mathrm{H}$ NMR data were recorded with 8 scans, 2 seconds of relaxation delay, and $20 \mathrm{~Hz}$ of spin rate. 


\section{Scanning Electron Microscopy (SEM)}

The surface and cross-sectional morphology of the films were characterized using scanning electron microscopy (SEM, Zeiss ULTRA 55 analytical SEM, Carl Zeiss AG, Germany). Cross-sectional SEM samples were prepared by cryo-fracturing the films in liquid nitrogen. A Denton desk V sputter coater (Denton Vacuum, Moorestown, NJ) was used to coat the films with $10-20 \mathrm{~nm}$ of Au before imaging to ensure sufficient sample surface conductivity. The SEM was operated at a voltage of $5 \mathrm{kV}$ using an InLens detector.

\subsubsection{Pure gas permeability measurement}

Pure gas permeabilities of helium $(\mathrm{He}), \mathrm{P}_{\mathrm{He}}$, and nitrogen $\left(\mathrm{N}_{2}\right), \mathrm{P}_{\mathrm{N}_{2}}$, were measured by a constant-volume variable-pressure method [39] at $35^{\circ} \mathrm{C}$ and 10 atm with ultra-high purity grade gases (UHP 99.999\%, Air Gas, Austin, TX). Membranes for gas permeation tests were mounted in a $47 \mathrm{~mm}$ HP Filter Holder (Millipore, Billerica, MA). Membranes were masked with a brass sheet (McMaster-Carr \# 9011K4, Atlanta, GA) and sealed with epoxy (Devcon \#145250, Danvers, MA). The area of each sample was measured using ImageJ software [40]. The upstream pressure was measured by a STJE 1000 psig pressure transducer (Honeywell Sensotec, Columbus, OH), and the downstream pressure was measured by a Baratron 626A 10 torr capacitance manometer (MKS, Andover, MA). The downstream pressure was kept below 10 torr by connecting to a vacuum pump. The gas feed pressure was changed from 2 atm to 18 atm, and National Instruments LabVIEW software was used to record the data. Permeability values are reported in Barrers, where 1 Barrer $=\frac{10^{-10} c c(S T P) \cdot c m}{c m^{2} \cdot s \cdot c m H g}$. 


\section{RESULTS AND DISCUSSION}

Each melt extruded BPS-20K/PEG film had a uniform thickness ranging from 20$40 \mu \mathrm{m}$. Table 3 summarizes the composition of the solvent cast and extruded BPS20K/PEG films; Figure 2 provides the surface and cross-section SEM images for each film.

Table 3 Preparation methods and film compositions of BPS-20K/PEG films used in this study

\begin{tabular}{ccccc}
\hline Figure 2 & Preparation & Polymer & $\begin{array}{c}\text { PEG } \overline{\mathrm{M}}_{\mathrm{n}} \\
{[\mathrm{g} / \mathrm{mol}]}\end{array}$ & $\begin{array}{c}\text { PEG } \\
\text { concentration } \\
{[\mathrm{wt} \%]}\end{array}$ \\
\hline$[\mathrm{a}]$ & Solution & BPS-20K & - & - \\
{$[\mathrm{b}]$} & Extrusion & BPS-20K & PEG 200 & 20 \\
{$[\mathrm{c}]$} & Extrusion & BPS-20K & PEG 200 & 30 \\
{$[\mathrm{~d}]$} & Extrusion & BPS-20K & PEG 300 & 20 \\
{$[\mathrm{e}]$} & Extrusion & BPS-20K & PEG 400 & 20 \\
\hline
\end{tabular}




\begin{tabular}{l|l|l}
\hline Sample Picture & SEM surface images & SEM cross-section images \\
\hline
\end{tabular}

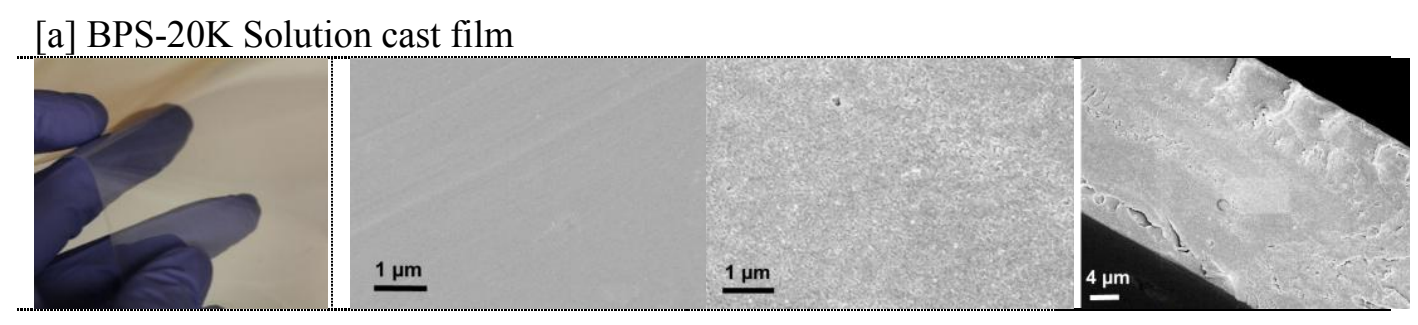

[b] BPS-20K/PEG $20020 \mathrm{wt} \%$ Extruded film

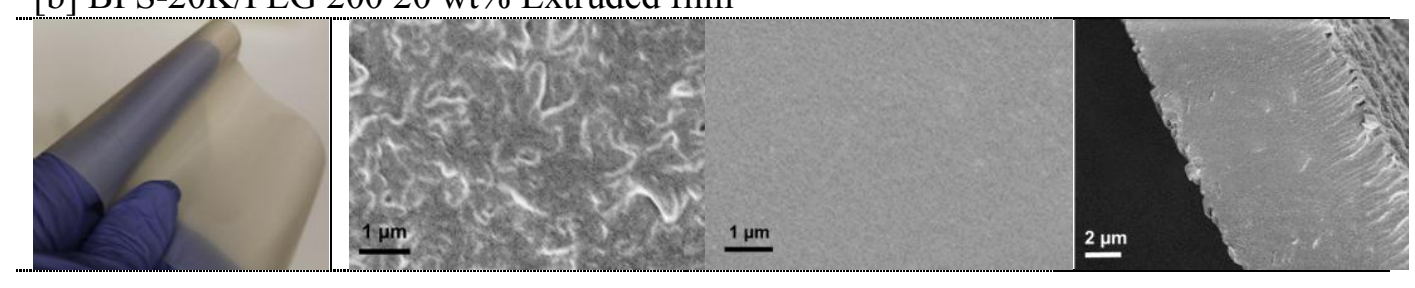

[c] BPS-20K/PEG $20030 \mathrm{wt} \%$ Extruded film

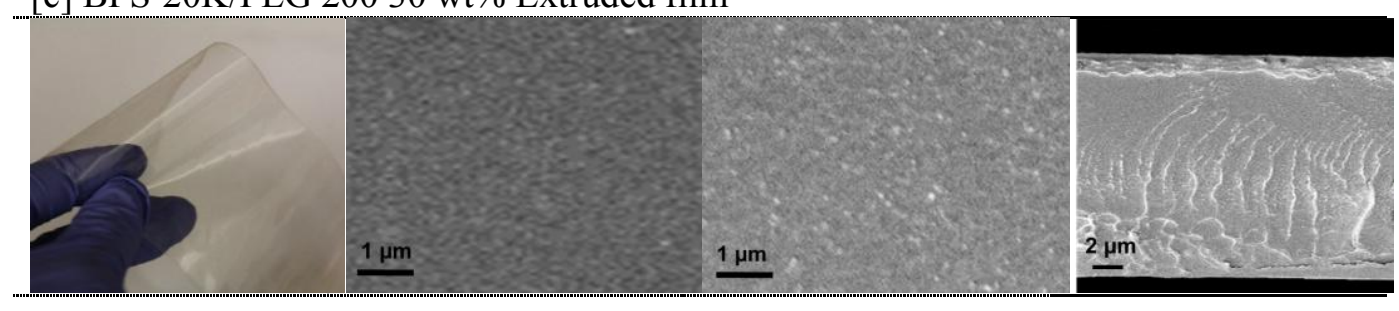

[d] BPS-20K/PEG $30020 \mathrm{wt} \%$ Extruded film

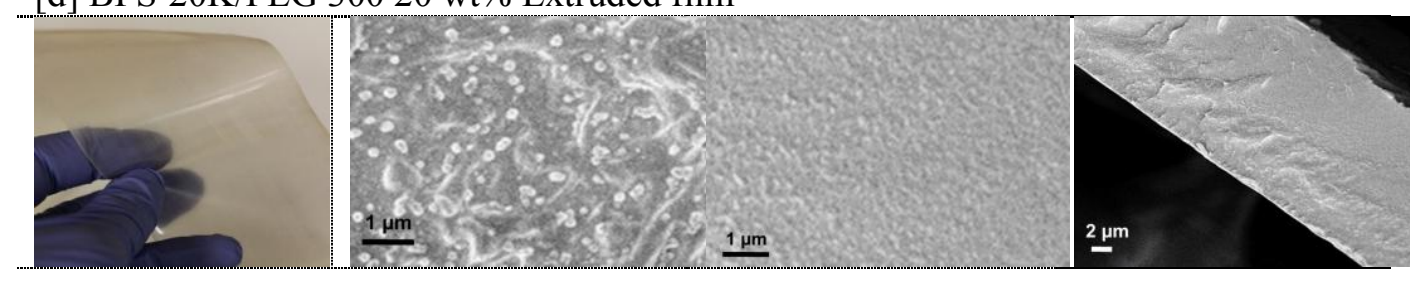

[e] BPS-20K/PEG $40020 \mathrm{wt} \%$ Extruded film

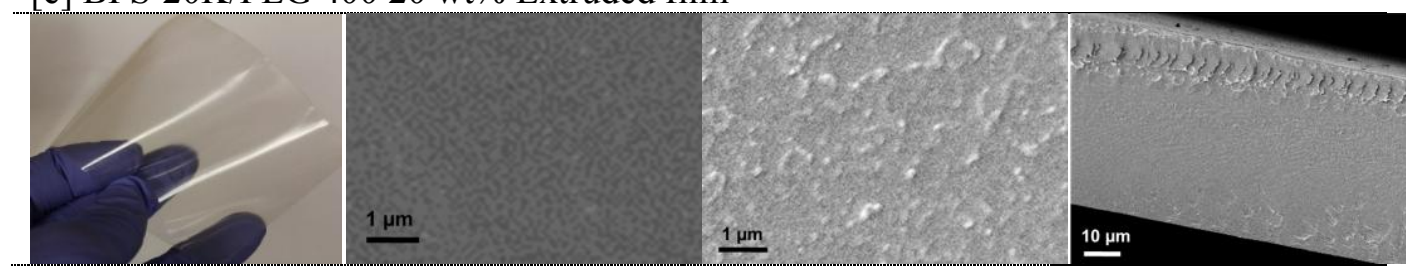

Figure 2 Sample pictures and SEM surface and cross-section images of [a] solution cast BPS-20K film, and [b] [e] extruded BPS-20K/PEG films. 


\subsection{Chemical structural characterization of BPS-20K/PEG films}

To confirm if melt extrusion of BPS-20K/PEG blends induced any thermal degradation, we used ${ }^{1} \mathrm{H}$ NMR analysis to determine the molecular structure, the PEG $\bar{M}_{n}$, the PEG concentration, and the BPS sulfonation level of the extruded films, as shown in Table 4 and Figure 3. The PEG $\bar{M}_{n}$, PEG concentration, and the BPS sulfonation level were calculated using methods reported in the literature $[14,17]$.

Table 4 PEG molecular weight, PEG concentration, and sulfonation level of BPS in the extruded BPS-20K/PEG films determined by ${ }^{1} \mathrm{H}$ NMR.

\begin{tabular}{ccccccc}
\hline Preparation & Polymer & $\begin{array}{c}\text { PEG } \\
\bar{M}_{n} \\
{[\mathrm{~g} / \mathrm{mol}]}\end{array}$ & $\begin{array}{c}\text { Intended PEG } \\
\text { concentration } \\
{[\mathrm{wt} \%]}\end{array}$ & $\begin{array}{c}\text { PEG } \\
\bar{M}_{n}\end{array}$ & $\begin{array}{c}\text { PEG } \\
\text { concentration } \\
{[\mathrm{g} / \mathrm{mol}]}\end{array}$ & $\begin{array}{c}\text { Sulfonation } \\
\text { level } \\
{[\mathrm{wt} \%}\end{array}$ \\
\hline Extrusion & BPS-20K & 200 & 20 & 220 & 19.4 & 20.8 \\
Extrusion & BPS-20K & 200 & 30 & 230 & 29.1 & 21.4 \\
Extrusion & BPS-20K & 300 & 20 & 300 & 22.2 & 21.4 \\
Extrusion & BPS-20K & 400 & 20 & 430 & 22.0 & 21.4 \\
\hline
\end{tabular}

The molecular structures and $\bar{M}_{n}$ of PEGs are unchanged, as Figure $3 \mathrm{~b}$ shows, and no peaks from degradation (e.g., oxygenated products) are detected. Although all extruded films were analyzed by ${ }^{1} \mathrm{H}$ NMR, only the BPS-20K/PEG $20020 \mathrm{wt} \%$ film is shown in Figure 3, since PEG 200 is the least stable of the PEGs used in this study. The PEG concentration values determined by ${ }^{1} \mathrm{H}$ NMR are consistent with the intended PEG amounts in the extruded films, within the uncertainty of measurements (Figure 3e).

Since sulfonated groups are susceptible to thermal degradation, the sulfonation levels (mol\%) of BPS in the extruded films were verified in order to probe any molecular structural change of BPS-20K during melt extrusion. Lee and others reported that BPS polymers underwent thermal desulfonation at $375 \sim 420{ }^{\circ} \mathrm{C}$ [22]. The extrusion temperatures employed in this study were much lower than the thermal desulfonation temperature. However, we wanted to ensure that the BPS-20K polymer, which we 
thought might exhibit a weaker thermal stability because of the presence of PEGs in blends [17], was stable during extrusion. The molecular structures of BPS-20K are not changed, as shown in Figure 3d, and the calculated sulfonation levels are in the range between 20 and $22 \mathrm{~mol} \%$, indicating thermal stability of the BPS-20K polymer during extrusion in this study. Note that the as-received BPS-20K polymers have sulfonation levels ranging from 20 to $22 \mathrm{~mol} \%$.
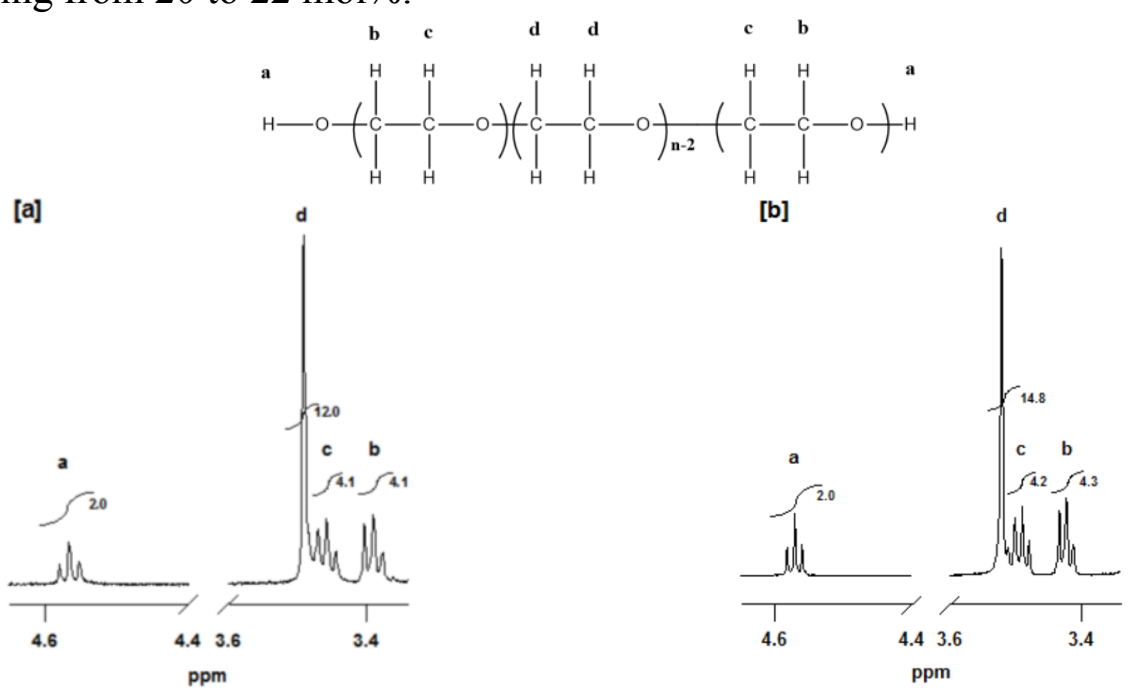

As-received PEG 200 Extruded BPS-20K/PEG $20020 \mathrm{wt} \%$ film

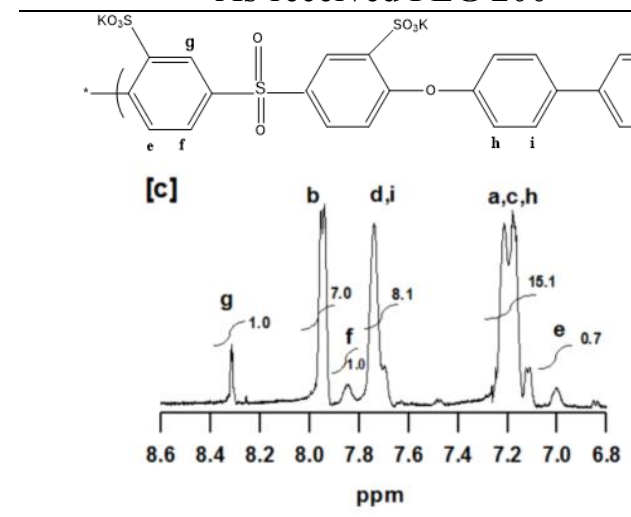

As-received BPS-20K

Extruded BPS-20K/PEG $20020 \mathrm{wt} \%$ film 


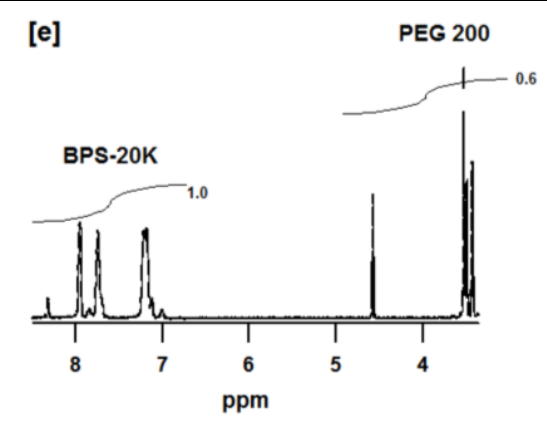

Extruded BPS-20K/PEG $20020 \mathrm{wt} \%$ film

Figure $3 \quad{ }^{1} \mathrm{H}$ NMR spectra of [a] as-received PEG 200, [b, d, e] the extruded BPS20K/PEG $20020 \mathrm{wt} \%$ film, and [c] as-received BPS-20K. The numbers next to each peak are the integrated ratios of proton peaks.

To complement the ${ }^{1} \mathrm{H}$ NMR analysis, FT-IR was employed to characterize the chemical structure of the extruded BPS-20K/PEG films. Figure 4 shows the FT-IR spectra $\left(4000 \sim 600 \mathrm{~cm}^{-1}\right)$ of selected films. Compared to the spectra of solution cast BPS-20K film, the extruded BPS-20K/PEG films show increased absorbance at 2700 $3000 \mathrm{~cm}^{-1}$ and $900 \sim 950 \mathrm{~cm}^{-1}$ in the presence of PEGs; these absorption bands are consistent with those of PEG materials [17]. For the sake of brevity, Figure 4 shows the FT-IR spectra of only PEG 200, but the spectra of other PEG materials were similar to that of PEG 200. Except for the presence of PEG absorbance band, no significant changes were detected in the FT-IR spectra of extruded BPS-20K/PEG films.

Based on ${ }^{1} \mathrm{H}$ NMR and FT-IR analysis, the melt extrusion within the processing temperature range in this study does not change the chemical structures or compositions of the extruded BPS-20K/PEG films. 


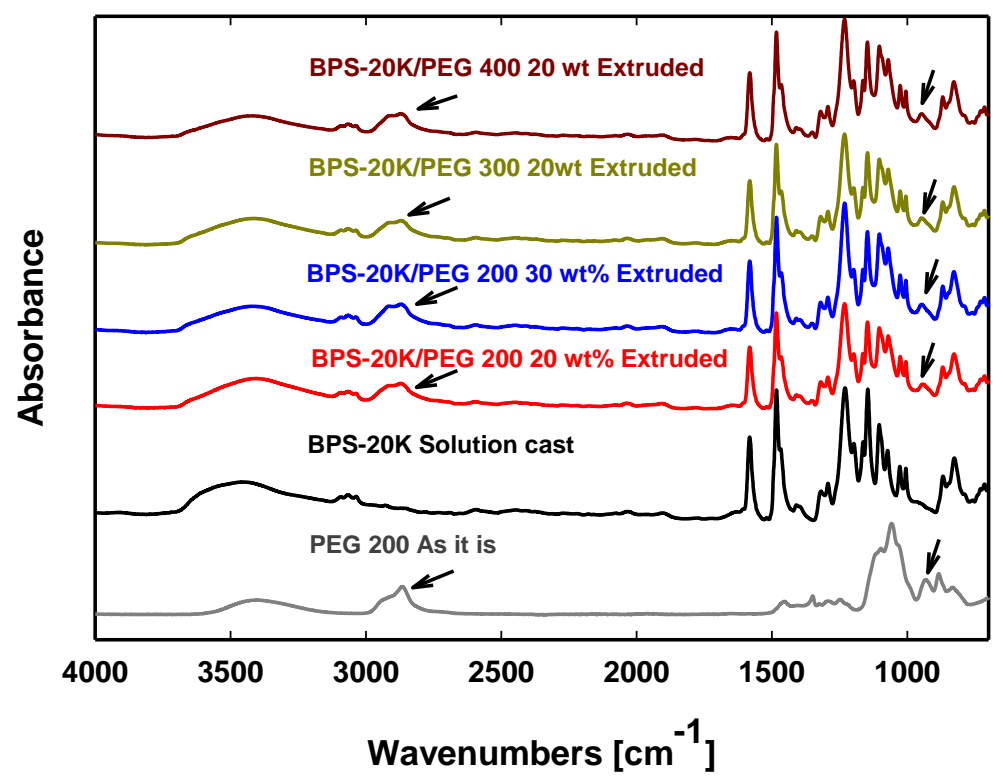

Figure 4 FT-IR (ATR mode) spectra of PEG $200 \mathrm{~g} / \mathrm{mol}$, solution cast BPS-20K film and extruded BPS-20K/PEG films. FT-IR spectra have been displaced vertically for easier viewing. The arrows denote stretching vibrations at $2700 \sim 3000 \mathrm{~cm}^{-1}$ (Left) and 900 950 $\mathrm{cm}^{-1}$ (Right).

\subsection{The origin of opacity in some extruded films}

Compared to the transparent BPS-20K solution cast film (Figure 2a) of 30 40 $\mu \mathrm{m}$ thickness, two of the extruded films (BPS-20K/PEG $20020 \mathrm{wt} \%$ in Figure 2b, and BPS20K/PEG $30020 \mathrm{wt} \%$ in Figure 2d) are somewhat opaque when stretched to similar thicknesses. When no drawing force is applied to the film, the as-extruded films of all compositions are transparent; however, the whitening effect occurs when a certain drawing force is applied, and some films become rather opaque. Thin film opaqueness may occur for several reasons, such as crystallization (PEG materials are semicrystalline), phase separation, surface roughness, and/or micro-void formation.

First, to confirm whether phase separation and/or crystallization underlie the opacity of the extruded films, DSC was run using the transparent and opaque parts of the same BPS-20K/PEG $20020 \mathrm{wt} \%$ films as shown in Figure 5. Note that although all 
extruded films were analyzed by DSC, only the BPS-20K/PEG $20020 \mathrm{wt} \%$ film thermograms are shown in Figure 5, for brevity. Consistent with previous literature [17, $18,22]$, BPS and PEG materials are miscible, and a single $T_{\mathrm{g}}$ was observed in both thermograms regardless of optical characteristics, indicating that phase separation is not the cause of the opacity. These $T_{\mathrm{g}}$ values are identical in each films (i.e., transparent and opaque films) and are in a range similar to the estimated $T_{\mathrm{g}}$ values using the Fox equation [17]. The broad transition beside the $T_{\mathrm{g}}$ between $-20{ }^{\circ} \mathrm{C}$ and $80{ }^{\circ} \mathrm{C}$ is related to the moisture absorbed by the hygroscopic PEGs, and/or PEG relaxation, as consistent with previous reports [17, 41-47]. The DSC thermograms of other extruded films also revealed a single $T_{\mathrm{g}}$, similar to the thermograms in Figure 5 .

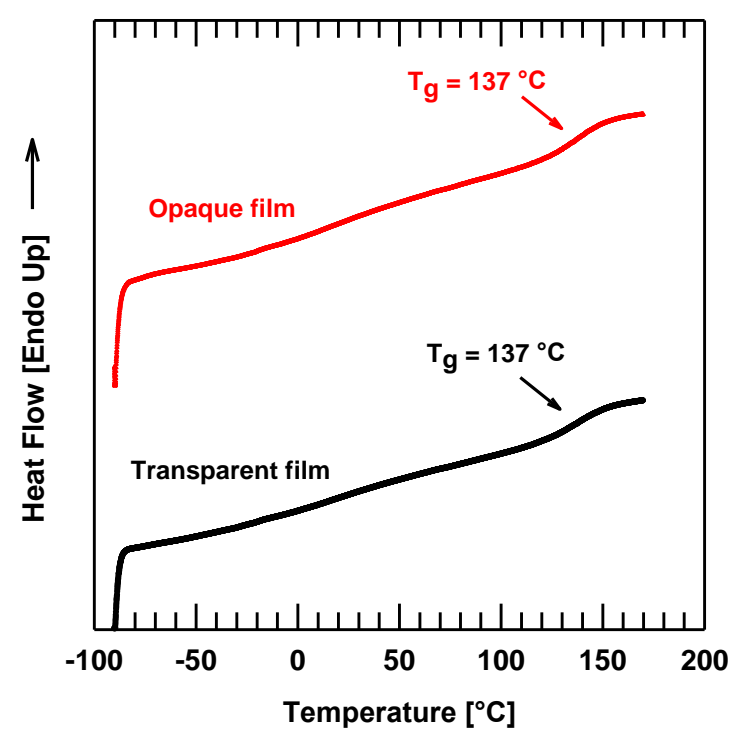

Figure 5 Final scan DSC thermograms of opaque and transparent parts of BPS20K/PEG $20020 \mathrm{wt} \%$ extruded films. The thermograms have been displaced vertically for clarity. The arrows denote the location of the glass transition temperature $\left(T_{\mathrm{g}}\right)$. The samples were run using a heating rate of 20 ${ }^{\circ} \mathrm{C} /$ min under nitrogen purge. 
Secondly, to confirm whether the opacity was due to micro-voids formed during stretching, the surface and cross-sectional morphology of the extruded BPS-20K/PEG films were characterized by scanning electron microscopy (SEM). When an axial drawing force is applied, some thermoplastics generate micro-voids in the films [12]. If the voids or clusters of voids have dimensions similar to or larger than the wavelength of visible light (i.e., 380 750 nm), the films can appear white or opaque due to light scattering. Note that, in some cases, this void formation does not significantly affect the mechanical properties of the films [48].

Because of the difficulties in cryo-fracturing of thin, soft material films such as ours $[49,50]$, some samples show cracks at the cross-sectional area; these cracks were introduced during cryo-fracturing. Also, some images show burn marks induced by the electron beam, which is also unavoidable for soft materials, as previously reported [50$52]$.

The surface and cross-section SEM images are exhibited in Figure 2. The surfaces of transparent films, including the solution cast BPS-20K film (Figure 2a), extruded BPS20K/PEG $20030 \mathrm{wt} \%$ film (Figure 2c), and BPS-20K/PEG $40020 \mathrm{wt} \%$ film (Figure 2e), are smooth and similar to each other. On the other hand, the surfaces of the rather opaque films, including the extruded BPS-20K/PEG $20020 \mathrm{wt} \%$ film (Figure 2b) and BPS20K/PEG $30020 \mathrm{wt} \%$ film (Figure 2d), are rough and qualitatively different from the smooth surface of the solution cast BPS-20K film. The roughness of these opaque films is limited to the surface: the cross-section images of these opaque films are similar to those of transparent films, and no micro-voids with dimensions of $300 \sim 800 \mathrm{~nm}$ were detected.

To further confirm whether micro-voids are present across the films, the gas $\left(\mathrm{N}_{2}\right.$ and $\mathrm{He}$ ) permeabilities of selected films were measured and are summarized in Table 5. 
The pure gas permeation tests, using a constant-volume variable-pressure method, were conducted to check for the presence of porosity [39]. Nitrogen $\left(\mathrm{N}_{2}\right)$ and helium $(\mathrm{He})$ were selected because $\mathrm{N}_{2}$ represents a low permeability gas (kinetic diameter $=3.64 \dot{\mathrm{A}}$, and molecular weight $=28 \mathrm{~g} / \mathrm{mol}$ ), and $\mathrm{He}$ represents a high permeability gas (kinetic diameter $=2.6 \dot{\mathrm{A}}$, and molecular weight $=4 \mathrm{~g} / \mathrm{mol}$ ) [53]. Measurements were taken at five different pressures $(2,6,10,14$, and $18 \mathrm{~atm})$ at $35^{\circ} \mathrm{C}$, as shown in Figure 6 , and the permeability values at $10 \mathrm{~atm}$ at $35^{\circ} \mathrm{C}$ are reported in Table 5.

PEG molecules were extracted from the extruded BPS-20K/PEG $20020 \mathrm{wt} \%$ films by soaking the films in deionized water at $75^{\circ} \mathrm{C}$ for 2 days; this extruded/extracted film was then used for gas permeability measurements. (Note that the remaining PEG concentration after extracting PEG was less than $0.5 \mathrm{wt} \%$ by ${ }^{1} \mathrm{H}$ NMR analysis [28].) Since PEGs must be extracted from the extruded BPS-20K/PEG films before their use as desalination membranes for further studies, it was of interest to determine whether the PEG extraction would generate micro-voids in the extruded films. After PEG extraction, the films that were initially opaque remained so, and the transparent films were qualitatively unchanged. The opaque films maintained their surface roughness, as shown in the SEM images in Figure 7. SEM cross-sections of the PEG-extracted film were free of micro-voids and qualitatively similar to those of solution cast BPS-20K films (see Figure 2a). 

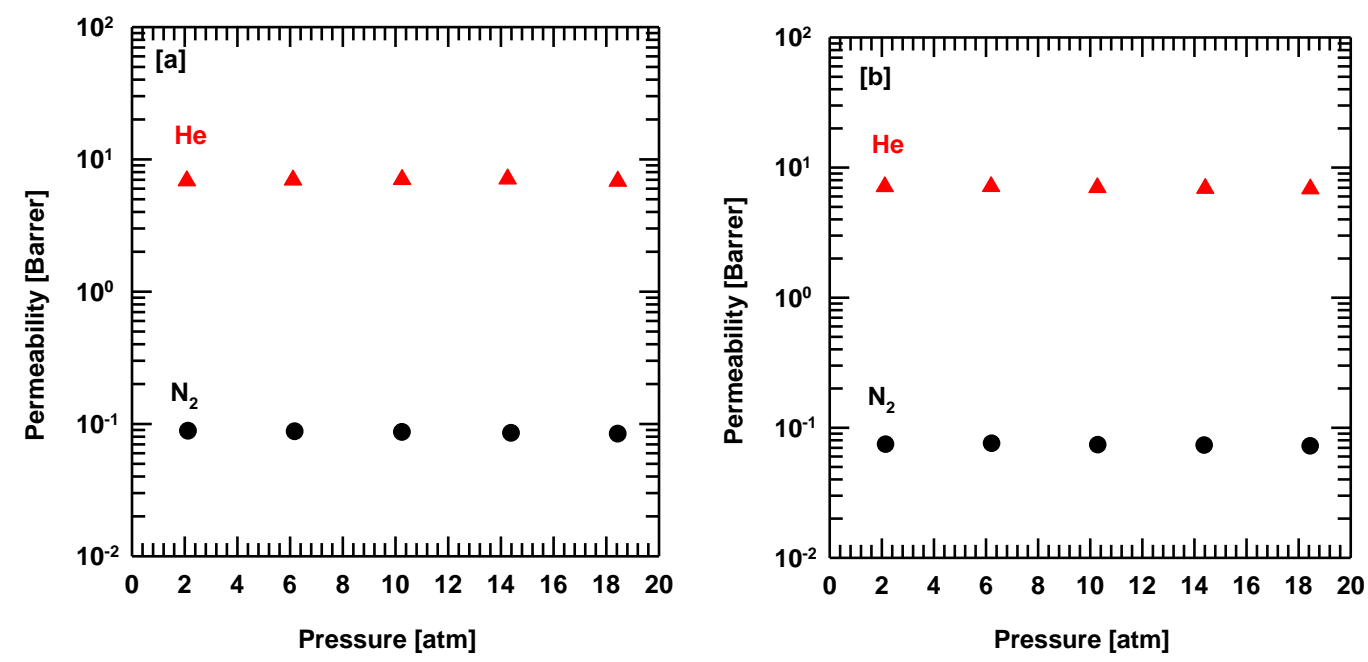

Figure 6 Nitrogen $\left(\mathrm{N}_{2}\right)$ and Helium $(\mathrm{He})$ gas permeability [Barrer] as a function of pressure at $35{ }^{\circ} \mathrm{C}$. [a] Solution cast BPS-20K film. [b] The extruded/extracted BPS-20K film. PEG 200 was extracted from the extruded BPS-20K/PEG $20020 \mathrm{wt} \%$ films by soaking in the deionized (DI) water at $75^{\circ} \mathrm{C}$ for 2 days.

Table 5 Gas $\left(\mathrm{N}_{2}\right.$ and $\left.\mathrm{He}\right)$ permeability of BPS-20K films prepared by solution casting method and melt extrusion.

\begin{tabular}{ccccccc}
\hline Polymer & $\begin{array}{c}\text { PEG M } \\
{[\mathrm{g} / \mathrm{mol}]}\end{array}$ & $\begin{array}{c}\text { PEG } \\
\mathrm{wt} \%\end{array}$ & Preparation & $\begin{array}{c}\mathrm{P}_{\mathrm{He}}{ }^{[\mathrm{a}]} \\
{[\mathrm{Barrer}]}\end{array}$ & $\begin{array}{c}\mathrm{P}_{\mathrm{N}_{2}}{ }^{[\mathrm{a}]} \\
{[\text { Barrer }]}\end{array}$ & $\mathrm{P}_{\mathrm{He}} / \mathrm{P}_{N_{2}}$ \\
\hline BPS-20K & - & - & Solution & $7.0 \pm 0.5$ & $0.087 \pm 0.007$ & 80 \\
BPS-20K & 200 & 20 & $\begin{array}{c}\text { PEG was } \\
\text { extracted* }\end{array}$ & $7.0 \pm 0.7$ & $0.073 \pm 0.007$ & 96 \\
\hline
\end{tabular}

${ }^{\text {[a] }}$ Measured using a constant-volume variable-pressure method [39]. $\mathrm{P}_{\mathrm{He}}$ and $\mathrm{P}_{\mathrm{N}_{2}}$ values were determined at $35{ }^{\circ} \mathrm{C}$ and $10 \mathrm{~atm}$. Permeability reported in Barrers, where 1 Barrer $=$ $\frac{10^{-10} c c(S T P) \cdot c m}{c m^{2} \cdot s \cdot c m H g}$

*The BPS-20K/PEG 20020 wt\% film was prepared by melt extrusion, and PEG 200 was extracted by soaking in the deionized (DI) water at $75{ }^{\circ} \mathrm{C}$ for 2 days. The film was then dried in the vacuum oven for 24 hours before measurements. 


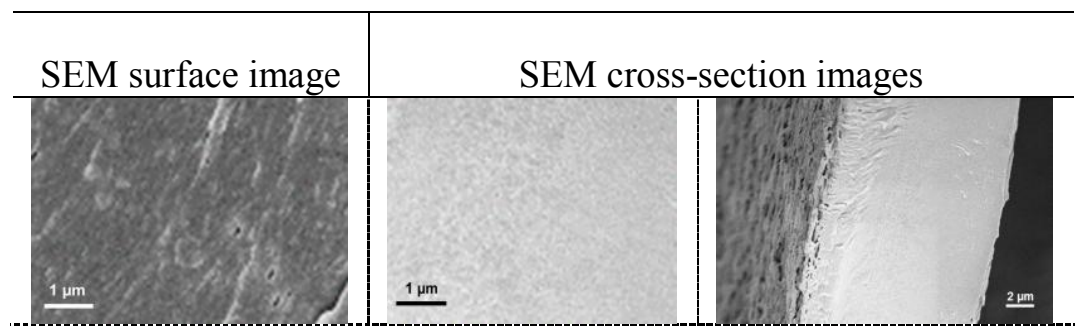

Figure 7 SEM images of surface, and cross-section of the extruded/extracted BPS20K films. PEG 200 was extracted from the extruded BPS-20K/PEG 20020 $\mathrm{wt} \%$ film by soaking in DI water at $75^{\circ} \mathrm{C}$ for 2 days.

The gas permeabilities of the extruded/extracted BPS-20K film are in a range similar to those of the solution cast BPS-20K film, within the uncertainty of measurements. The permeability values calculated from individual gas permeation tests at different pressures (2 18 atm) correspond to each other (see Figure 6). If there were any micro-voids with dimensions of $300 \sim 800 \mathrm{~nm}$, as mentioned earlier, the gas permeability would not be consistent over the pressure range.

In general, single gas transport in porous media can be explained by Knudsen diffusion and viscous flow [54-57]. Knudsen diffusion occurs when pore radius is comparable to or smaller than the mean free path of the gas molecules $(\lambda)$ involved. The process is, then, more governed by collisions with the pore walls than intermolecular collisions. Gas transport in the Knudsen regime is inversely proportional to the square root of the molecular weight of the gas penetrants; thus, gas selectivity, $\alpha_{A / B}\left(=\mathrm{P}_{A} / \mathrm{P}_{B}\right)$, of Knudsen diffusion can be expressed as follows :

$$
\alpha_{A / B}=\frac{\sqrt{M_{B}}}{\sqrt{M_{A}}}
$$

If the $\mathrm{He}$ and $\mathrm{N}_{2}$ transport across our membranes is in the Knudsen regime, gas selectivity should be around 3.

When pore radius (r) is much greater than mean free path of the gas molecules $(\lambda)$ $(\mathrm{r}>>\lambda)$, viscous flow dominates the gas transport mechanism. This indicates that gas 
transport through structural defects in membranes such as pinholes would be governed by viscous flow, and the resultant flux should increase proportional to the increasing upstream pressure applied to the membrane.

However, our results show that $\mathrm{He}$ permeability is much higher than $\mathrm{N}_{2}$ permeability $\left(\mathrm{P}_{\mathrm{He}} \gg \mathrm{P}_{\mathrm{N}_{2}}\right)$, and gas permeability values are independent of upstream pressure. In addition, the gas selectivity $\left(\mathrm{P}_{\mathrm{He}} / \mathrm{P}_{N_{2}}\right)$ values of our films are in the range of 80-96. The gas permeation results confirm that the extruded/extracted film does not have micro-voids with dimensions of $300 \sim 800 \mathrm{~nm}$.

The results are consistent with the cross-section and surface morphologies of the extruded films, meaning that the origin of the opaqueness in two extruded BPS-20K/PEG films is surface roughness, and not phase-separation, crystallization, and/or micro-voids. Similar observations relating surface topology to opaqueness in polymer films can be found elsewhere [58-61].

The reason for the surface roughness in two extruded films (films containing 20 wt $\%$ of PEG 200 and 300) is not yet clear, but it could be due to the evaporation of low molar mass constituents in low molecular weight PEG material from the film surface during stretching. Oh et al. previously reported the loss of low molecular weight species of PEG 200 during the isothermal hold at high temperatures between $210{ }^{\circ} \mathrm{C}$ and $260{ }^{\circ} \mathrm{C}$ [17]. They reported that ${ }^{1} \mathrm{H}$ NMR and FT-IR do not exhibit significant changes in chemical structure of PEG during the isothermal hold, whereas the $\bar{M}_{n}$, PDI, and $T_{\mathrm{g}}$ of PEG increase somewhat with high temperature exposure. This observation is consistent with the loss of low molecular weight constituents due to evaporation. Similarly, the low molecular species evaporation from the surface of the extruded films containing low molecular weight PEGs (PEGs 200 and 300) at lower PEG concentration (PEG 20 wt\%) could lead to somewhat higher viscosities of the blends at the surface, resulting in surface 
roughness during stretching. On the other hand, low molecular species evaporation from the surface of the extruded films containing high molecular weight PEG (i.e., BPS20K/PEG $40020 \mathrm{wt} \%$ ) and higher PEG concentration (i.e., BPS-20K/PEG $20030 \mathrm{wt} \%$ ) may have little effect on the viscosities of surface blends, resulting in smooth surfaces.

These extruded BPS/PEG films will be used for further studies, and subsequent papers will report the PEG extraction kinetics from the extruded films before their use as desalination membranes, and the water and salt transport properties of these membranes.

\section{Conclusions}

In this study, single layer, uniform thickness membranes of BPS-20K/PEG blends were successfully prepared by solvent-free melt extrusion. Based on the ${ }^{1} \mathrm{H}$ NMR and FT-IR analysis, melt extrusion within the processing temperature range in this study does not change the chemical structures and compositions of the extruded BPS-20K/PEG films. The chemical structure and cross-sectional morphologies of extruded films are comparable to those of solution cast films. Some extruded BPS-20K/PEG $20 \mathrm{wt} \%$ films were rather opaque because of surface roughness. Other factors that could lead to film inhomogeneity, such as phase separation, crystallization, and micro-voids were not found.

\section{ACKNOWLEDGEMENTS}

This work was supported by NSF Science and Technology Center for Layered Polymeric Systems (Grant 0423914). Work at the Molecular Foundry was supported by the Office of Science, Office of Basic Energy Sciences, of the U.S. Department of Energy under Contract No. DE-AC02-05CH11231. We thank Benny Freeman for his help and guidance. We appreciated help from Dr. Sue Mecham at Virginia Polytechnic Institute and State University for SEC analysis. Equipment for SEC analysis was funded by NSF- 
MRI (grant 1126534) at Virginia Polytechnic Institute and State University. We also thank Dr. Ben Shoulders in the Department of Chemistry at the University of Texas at Austin for his help to analyzed ${ }^{1} \mathrm{H}$ NMR data.

\section{REFERENCES}

[1] W. Xie, G. M. Geise, B. D. Freeman, H.-S. Lee, G. Byun, and J. E. McGrath, "Polyamide interfacial composite membranes prepared from m-phenylene diamine, trimesoyl chloride and a new disulfonated diamine," Journal of Membrane Science, vol. 403-404, pp. 152-161, 2012.

[2] R. J. Petersen, "Composite reverse osmosis and nanofiltration membranes," Journal of Membrane Science, vol. 83, pp. 81-150, 1993.

[3] C. Linder and O. Kedem, "History of nanofiltration membranes 1960 to 1990," in Nanofiltration: principles and applications, A. I. Schafer, A. G. Fane, and T. D. Waite, Eds., ed New York: Elsevier, 2003.

[4] M. Y. Kariduraganavar, R. K. Nagarale, A. A. Kittur, and S. S. Kulkarni, "Ionexchange membranes: preparative methods for electrodialysis and fuel cell applications," Desalination, vol. 197, 2006.

[5] M. Heinzer, M. Lee, R. Van Houten, O. Lane, J. E. McGrath, and D. G. Baird, "Effects of solvent-casting conditions on the morphology and properties of highly fluorinated poly(arylene ethersulfone) copolymer films for polymer electrolyte membranes," Annual Technical Conference - Society of Plastics Engineers, vol. 67, pp. 606-610, 2009.

[6] R. W. Baker, Membrane technology and applications, 3rd ed. West Sussex, United Kingdom: John Wiley and Sons Ltd, 2012.

[7] W. Xie, J. Cook, H. B. Park, B. D. Freeman, C. H. Lee, and J. E. McGrath, "Advances in membrane materials: desalination membranes based on directly copolymerized disulfonated poly(arylene ether sulfone) random copolymers," Water Science and Technology: a Journal of the International Association on Water Pollution Research, vol. 61, pp. 619-624, 2010.

[8] W. Xie, G. M. Geise, B. D. Freeman, C. H. Lee, and J. E. McGrath, "Influence of processing history on water and salt transport properties of disulfonated polysulfone random copolymers," Polymer, vol. 53, pp. 1581-1592, 2012.

[9] W. Xie, J. Cook, H. B. Park, B. D. Freeman, C. H. Lee, and J. E. McGrath, "Fundamental salt and water transport properties in directly copolymerized disulfonated poly(arylene ether sulfone) random copolymer," Polymer, vol. 52, pp. 2244-2254, 2011.

[10] F. Wang, M. Hickner, Y. S. Kim, T. A. Zawodzinski, and J. E. McGrath, "Direct polymerization of sulfonated poly(arylene ether sulfone) random(statistical) copolymer: candidates for next proton exchange membranes," Journal of Membrane Science, vol. 197, pp. 231-242, 2002. 
[11] H. B. Park, B. D. Freeman, Z.-B. Zhang, M. Sankir, and J. E. McGrath, "Highly chlorine-tolerant polymers for desalination," Angewandte Chemie International Edition vol. 47, pp. 6019-6024, 2008.

[12] C. Yu, J. R. Rowlett, C. H. Lee, O. R. Lane, D. Van Houten, M. Zhang, et al., "Synthesis and characterization of multiblock partially fluorinated hydrophobic poly(arylene ether sulfone)-hydrophilic disulfonated poly(arylene ether sulfone) copolymers for proton exchange membranes," Journal of Polymer Science, Part A: Polymer Chemistry, vol. 51, pp. 2301-2310, 2013.

[13] A. Roy, M. A. Hickner, H.-S. Lee, A. Badami, X. Yu, Y. Li, et al., "Transport properties of proton exchange membranes," ECS Transactions, vol. 20, pp. 45-54, 2006.

[14] Y. Li, F. Wang, J. Yang, D. Liu, A. Roy, S. Case, et al., "Synthesis and characterization of controlled molecular weight disulfonated poly(arylene ether sulfone) copolymers and their applications to proton exchange membranes," Polymer, vol. 47, pp. 4210-4217, 2006.

[15] Y. S. Kim, L. Dong, M. A. Hickner, B. S. Pivovar, and J. E. McGrath, "Processing induced morphological development in hydrated sulfonated poly(arylene ether sulfone) copolymer membranes," Polymer, vol. 44, pp. 57295736, 2003.

[16] J. Huang, D. G. Baird, and J. E. McGrath, "Continuous solution casting and properties of sulfonated poly(arylene ether sulfone) copolymer membranes for fuel cells," Annual Technical Conference - Society of Plastics Engineers, vol. 66, pp. 69-73, 2008.

[17] H. J. Oh, B. D. Freeman, J. E. McGrath, C. H. Lee, and D. R. Paul, "Thermal analysis of disulfonated poly(arylene ether sulfone) plasticized with poly(ethylene glycol) for membrane formation," Polymer vol. 55, pp. 235-247, 2014.

[18] H. J. Oh, B. D. Freeman, J. E. McGrath, C. J. Ellison, S. Mecham, K.-S. Lee, et al., "Rheological studies of disulfonated poly(arylene ether sulfone) plasticized with poly(ethylene glycol) for membrane formation," Polymer, vol. 55, pp. 15741582, 2014.

[19] J.-Y. Sanchez, C. Iojoiu, Y. Piffard, N. E. Kissi, and F. Chabert, "Extrusion of a thermoplastic polymer bearing acid ionic groupings," United States Patent No. 7956095 B2 Patent, 2011.

[20] J.-Y. Sanchez, C. Iojoiu, R. Mercier, M. Marechal, N. E. Kissi, H. Galiano, et al., "Membrane preparation method comprising the extrusion of a thermoplastic polymer bearing alkaline groupings," United States Patent No. 7,973,089 B2 Patent, 2011.

[21] J.-Y. Sanchez, F. Chabert, C. Iojoiu, J. Salomon, N. E. Kissi, Y. Piffard, et al., "Extrusion: an environmentally friendly process for PEMFC membrane elaboration," Electrochimica Acta, vol. 53, pp. 1584-1594, 2007.

[22] C. H. Lee, D. VanHouten, O. Lane, J. E. McGrath, J. Hou, L. A. Madsen, et al., "Disulfonated poly(arylene ether sulfone) random copolymer blends tuned for 
rapid water permeation via cation complexation with poly(ethylene glycol) oligomers," Chemistry of Materials, vol. 23, pp. 1039-1049, 2011.

[23] P. Bebin and H. Galiano, "Processing of PEMFC membranes by extrusion: Part 1. sulfonated polysulfone in acid form," Advances in Polymer Technology, vol. 25, pp. 121-126, 2006.

[24] P. Bebin and H. Galiano, "Processing of sulfonated polysulfone for PEMFC membrane applications: Part 2. polymer in salt form," Advances in Polymer Technology, vol. 25, pp. 127-133, 2006.

[25] A. Noshay and L. M. Robeson, "Sulfonated polysulfone," Journal of Applied Polymer Science, vol. 20, pp. 1885-1903, 1976.

[26] R. A. Register and R. K. Prud'homme, "Melt rheology," in Ionomers, M. R. Tant, K. A. Mauritz, and G. L. Wilkes, Eds., ed: Blackie Academic \& Professional, 1997, pp. 208-260.

[27] A. Eisenberg and J. S. Kim, "Introduction to ionomers," ed: John Wiley \& Sons, Inc., 1998, pp. 1-16, 30-31, 38-85, 114-117, 244-266.

[28] H. J. Oh, "Sulfonated Polysulfone Desalination Membranes by Melt Extrusion," Ph.D. Dissertation, Department of Chemical Engineering, The University of Texas at Austin, 2015.

[29] Y. Molmeret, F. Chabert, N. E. Kissi, C. Iojoiu, R. Mercier, and J.-Y. Sanchez, "Toward extrusion of ionomers to process fuel cell membranes," Polymers, vol. 3, pp. 1126-1150, 2011.

[30] Y. Molmeret, F. Chabert, C. Iojoiu, N. E. Kissi, and J.-Y. Sanchez, "Extruded proton exchange membranes based on sulfonated polyaromatic polymers for fuel cell application," presented at the The XV International Congress on Rheology: The Society of Rheology 80th Annual Meeting, Monterey, CA, 2008.

[31] M. T. Ponting, A. Hiltner, and E. Baer, "Polymer nanostructures by forced assembly: process, structure, and properties," Macromolecular Symposia, vol. 294, pp. 19-32, 2010.

[32] M. T. Ponting, "Gradient multilayered films \& confined crystallization of polymer nanolayers by forced assembly coextrusion," Ph.D. Dissertation, Department of Macromolecular Science \& Engineering, Case Western Reserve University, 2010.

[33] M. T. Ponting, Y. Lin, J. K. Keum, A. Hiltner, and E. Baer, "Effect of substrate on the isothermal crystallization kinetics of confined poly( $\varepsilon$-caprolactone) nanolayers," Macromolecules, vol. 43, pp. 8619-8627, 2010.

[34] G. T. Offord, S. R. Armstrong, B. D. Freeman, E. Baer, A. Hiltner, J. S. Swinnea, et al., "Porosity enhancement in $\beta$ nucleated isotactic polypropylene stretched films by thermal annealing," Polymer, vol. 54, pp. 2577-2589, 2013.

[35] G. T. Offord, S. R. Armstrong, B. D. Freeman, E. Baer, A. Hiltner, and D. R. Paul, "Influence of processing strategies on porosity and permeability of $\beta$ nucleated isotactic polypropylene stretched films," Polymer, vol. 54, pp. 27962807, 2013.

[36] Y. S. Kim, M. A. Hickner, L. Dong, B. S. Pivovar, and J. E. McGrath, "Sulfonated poly(arylene ether sulfone) copolymer proton exchange membranes: 
composition and morphology effects on the methanol permeability," Journal of Membrane Science, vol. 243, pp. 317-326, 2004.

[37] M. Hickner, H. Ghassemi, Y. S. Kim, B. R. Einsla, and J. E. McGrath, "Alternative polymer systems for proton exchange membranes (PEMs)," Chemical Reviews, vol. 104, pp. 4587-4612, 2004.

[38] K. B. Wiles, F. Wang, and J. E. McGrath, "Directly copolymerized poly(arylene sulfide sulfone) disulfonated copolymers for PEM-based fuel cell systems. I. Synthesis and characterization," Journal of Polymer Science Part A: Polymer Chemistry, vol. 43, pp. 2964-2976, 2005.

[39] H. Czichos, T. Saito, and H. Smith, Springer handbook of materials measurement methods: Springer.

[40] http://rsb.info.nih.gov/ij/index.html.

[41] B. E. Read, "Mechanical relaxation in some oxide polymers," Polymer, vol. 3, pp. 529-542, 1962.

[42] N. G. McGrum, B. E. Read, and G. Williams, "Anelastic and dielectric effects in polymeric solids," ed UK: John Wiley \& Sons Ltd., 1947, pp. 308-312, 327331,431-434,551-561.

[43] M. Dionisio, A. C. Fernandes, J. F. Mano, N. T. Correia, and R. C. Sousa, "Relaxation studies in PEO/PMMA blends," Macromolecules, vol. 33, pp. 10021011, 2000.

[44] D. Q. M. Craig, "A review of thermal methods used for the analysis of the crystal form, solution thermodynamics and glass transition behavior of polyethylene glycols," Thermochimica Acta, vol. 248, pp. 189-203, 1995.

[45] G. Ceccorulli, M. Pizzoli, M. Scandola, G. C. Alfonso, and A. Turturro, "Dynamic mechanical relaxations of poly(vinylidene fluoride)poly(vinylpyrrolidone) blends," Polymer, vol. 30, pp. 1251-1256, 1989.

[46] S. W. Bigger, J. S. Delatycki, and N. C. Billingham, "Effect of frequency, molecular weight and thermal oxidation on the dynamic mechanical response of poly(ethylene oxide)," Polymer International, vol. 26, pp. 181-186, 1991.

[47] G. Allen, J. McAinsh, and G. M. Jeffs, "Relaxation phenomena in some aromatic polymers: effect of water content on the low temperature relaxation," Polymer, vol. 12, pp. 85-100, 1971.

[48] American Society of Metals, Characterization and failure analysis of plastics: ASM International.

[49] L. Sawyer, D. Grubb, and G. F. Meyers, Polymer Microscopy: Springe, 2008.

[50] G. H. Michler, "Problems associated with he electron microscopy of polymers," in Electron Microscopy of Polymers, ed: Springe, 2008.

[51] L. Reimer, "Review of the radiation damage problem of organic specimens," in Principles and Practice of Variable Pressure: Environmental Scanning Electron Microscopy (VP-ESEM), B. Siegel, Ed., ed: John Wiley \& Sons, 1975 pp. 231245.

[52] R. F. Egerton, P. Li, and M. Malac, "Radiation damage in the TEM and SEM," Micron, vol. 35, pp. 399-409, 2004. 
[53] S. Matteucci, Y. P. Yampolskii, and B. D. Freeman, "Transport of gases andvapors in glassy and rubbery polymers," in Materials science of membranes for gas and vapor separation, Y. P. Yampolskii, I. Piannau, and B. D. Freeman, Eds., ed The Atrium, Southern Gate, Chichester, West Sussex PO19 8SQ, England: Wiley, 2006, pp. 1-47.

[54] R. J. R. Uhlhorn and K. Keizer, "Gas and surface diffusion in modified $\gamma$-alumina systems," 1989.

[55] K. W. and C. R. Hohenthanner, "Mass transfer within the gas-phase of porous media," International Journal of Heat and Mass Transfer, vol. 43, pp. 807-823, 2000.

[56] S. Kim, J. R. Jinschek, H. Chen, D. S. Sholl, and E. Marand, "Scalable Fabrication of Carbon Nanotube/Polymer Nanocomposite Membranes for High Flux Gas Transport," Nano Letters, vol. 7, pp. 2806-2811, 2007.

[57] E. A. Mason, A. P. Malinauskas, and R. B. Evans III, "Flow and diffusion of gases in porous media," Journal of Chemical Physics vol. 46, pp. 3199-3216, 1967.

[58] Y. Hong, S. J. Coombs, J. J. Cooper-White, M. E. Mackay, C. J. Hawker, E. Malmstrom, et al., "Film blowing of linear low-density polyethylene blended with a novel hyperbranched polymer processing aid," Polymer, vol. 41, pp. 7705-7713, 2000.

[59] L. Zimmennann, M. Weibel, W. Caseri, and U. W. Suter, "High refractive index films of polymer nanocomposites," Journal of Materials Research, vol. 8, pp. 1742-1748, 199.

[60] R. Jayasekara, I. Harding, I. Bowater, G. B. Y. Christie, and G. T. Lonergan, "Preparation, surface modification and characterisation of solution cast starch PVA blended films," Polymer Testing, vol. 23, pp. 17-27, 2004.

[61] M. Benz, W. B. BEuler, and O. J. Gregory, "The Influence of Preparation Conditions on the Surface Morphology of Poly(vinylidene fluoride) Films," Langmuir, vol. 17, pp. 239-243, 2001. 


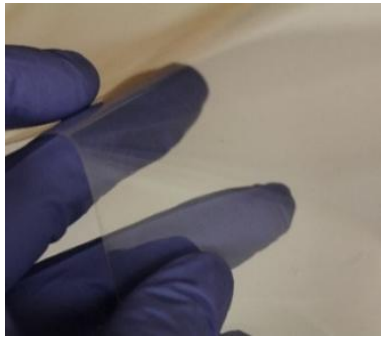

Solution cast BPS-20K film

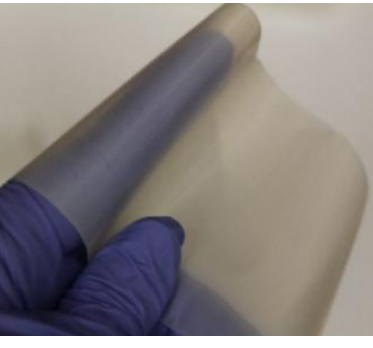

Extruded BPS-20K/PEG 200

$20 \mathrm{wt} \%$ film

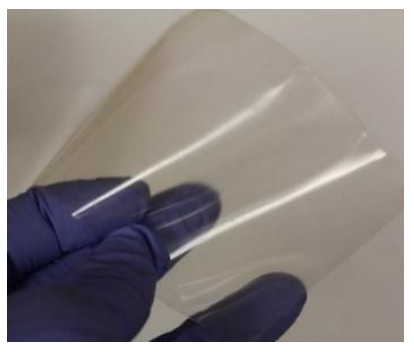

Extruded BPS-20K/PEG 400 $20 \mathrm{wt} \%$ film

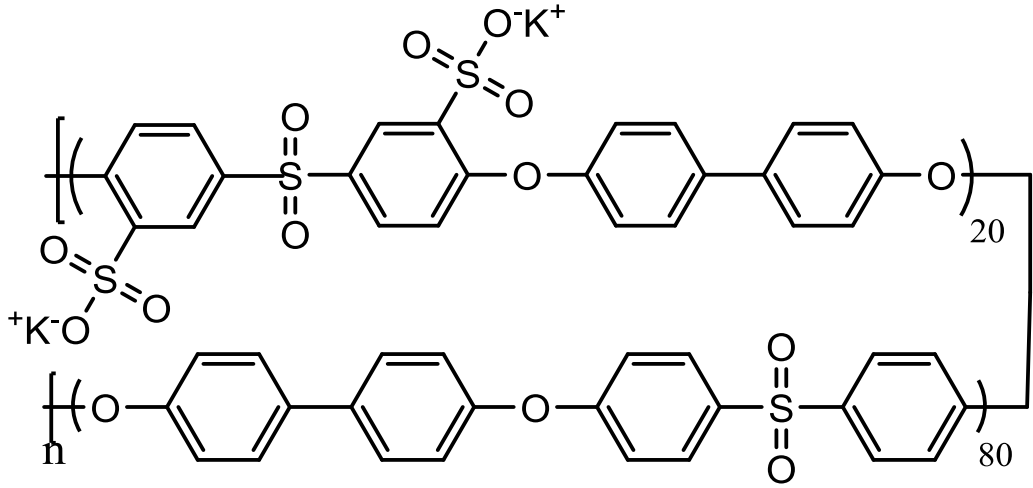

Sulfonated polysulfone (BPS)

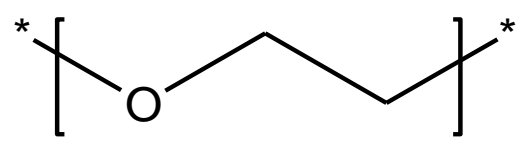

Poly(ethylene glycol) (PEG) 